\title{
PERSENTUHAN AGAMA ISAM DENGAN KEBUDAYAAN ASLI INDONESIA
}

\author{
Deni Miharja \\ Fakultas Ushuluddin UIN Sunan Gunung Djati \\ Jl. A.H. Haris Nasution 105 Cibiru, Bandung, 40614 \\ e-mail: miharjadeni@yahoo.co.id
}

\begin{abstract}
Abstrak: Islam masuk ke Indonesia tidak dalam kondisi hampa budaya. Telah ada budaya setempat yang berkembang dalam masyarakat Indonesia. Hal ini melahirkan akulturasi budaya antara ajaran Islam dan budaya masyarakat setempat. Di sisi lain, tata cara pelaksanaan ajaran Islam lebih bercorak keindonesiaan (lokal) dan tidak sepenuhnya sama dengan wilayah aslinya di Timur Tengah. Tulisan ini mengeksplorasi bagaimana persentuhan agama Islam dengan kebudayaan lokal Indonesia, terutama dengan budaya Sunda. Penulis menyimpulkan bahwa hampir seluruh ranah kehidupan orang Sunda mengandung nilai-nilai yang Islami. Ajaran dan hukum dalam masyarakat Sunda pun disosialisasikan melalui seni dan budaya, seperti pada lakon pewayangan (wayang golek), lagu-lagu, pantun, dan banyolan-banyolan. Ajaran Islam melalui media wayang golek meliputi Islam sebagai a way of life, termasuk ajaran dasar tentang ketatanegaraan dan pemerintahan. Ajaran Islam melalui pewayangan seringkali menekankan ketaatan kepada ajaran agama dan negara secara bersamaan dan berkesinambungan yang mencerminkan pemahaman atas perintah ketaatan kepada Allah, Rasul dan ûli al-amri sebagaimana diamanatkan dalam al-Qur'an.
\end{abstract}

\footnotetext{
Abstract: The Convergence of Islamic Religion with the Indonesian Indigenous Culture. When Islam first entered Indonesian archipelago, this land was not culturally an empty space. There had existed local culture and developed in the Indonesian society, that has led to cultural acculturation between Islamic teachings and indigenous culture. As such, the ways of observing Islamic teachings are of Indonesian character and not necessarily similar to that of its origin in the Middle East. This paper explores how the convergence of Islamic religious teachings and the Indonesian local culture, especially the Sundanese had occurred. The author concludes that almost all aspects of Sundanese social life have been influenced by the Islamic values. The teaching and law in the Sundanese society could also be associated through art and culture, in such as puppet show (wayang golek), songs, poetry and anecdotes. The Islamic teaching through puppet show has often emphasized obedience to both religious teachings and the state simultaneously as reflection of understanding the fulfillment of God's command, the Messenger and leader (ûli al-amri) found in the Qur'anic tenets.
} 
Kata Kunci : agama Islam, kebudayaan asli, akulturasi

\section{Pendahuluan}

Persentuhan agama Islam dengan kebudayaan asli Indonesia, tentu merupakan pembahasan yang menarik, di mana Islam sebagai agama universal merupakan rahmat bagi semesta alam, dan dalam kehadirannya di muka bumi ini, Islam berbaur dengan beragam kebudayaan lokal (local culture), sehingga antara Islam dan kebudayaan lokal pada suatu masyarakat tidak bisa dipisahkan, keduanya merupakan bagian yang saling mendukung dan menguatkan.

Islam sebagai agama yang diturunkan oleh Allah SWT. untuk semua umat manusia telah memainkan perannya di dalam mengisi kehidupan umat manusia di muka bumi ini. Kehadiran Islam di tengah-tengah masyarakat yang sudah memiliki kebudayaan tersendiri, menjadikan Islam dengan budaya setempat mengalami akulturasi, yang pada akhirnya tata pelaksanaan ajaran Islam menjadi beragam. Namun demikian, al-Qur'an dan hadis sebagai sumber hukum Islam tetap menjadi ujung tombak pada masyarakat yang mayoritas muslim, sehingga Islam begitu identik dengan keberagaman.

Al-Qur'an sebagai wahyu Allah, dalam pandangan dan keyakinan umat Islam adalah sumber kebenaran dan mutlak benarnya. Meskipun demikian, kebenaran mutlak itu tidak akan tampak manakala al-Qur'an tidak berinteraksi dengan realitas sosial, atau menurut Quraish Shihab, dibumikan, dibaca, dipahami, dan diamalkan. Ketika kebenaran mutlak itu disikapi oleh para pemeluknya dengan latar belakang kultural atau tingkat pengetahuan yang berbeda akan muncul kebenaran-kebenaran parsial, sehingga kebenaran mutlak tetap milik Tuhan ${ }^{1}$.

Berdasarkan hal tersebut, maka kebenaran dalam Islam yang dikatakan kebenaran yang mutlak itu bersumber dari Allah, sedangkan kebenaran yang parsial itu hadir pada realitas sosial suatu masyarakat yang kebenarannya akan relatif. Demikian pula, bahwa Islam tetap menghargai keberagaman kebenaran yang ada dalam masyarakat, termasuk keberagaman budaya yang dimiliki suatu masyarakat.

Quraish Shihab, dalam salah satu Kata Pengantar sebuah buku, pernah menyatakan bahwa berdasarkan analisis MB. Hooker, Robert Hefner, John L. Esposito, dan William Liddle, keberadaan Islam di Nusantara bercorak sangat spesifik di mana ekspresinya secara intelektual, kultural, sosial, dan politik bisa jadi, dan kenyataannya memang berbeda dengan ekspresi Islam yang berada di belahan dunia yang lain. Islam Indonesia merupakan perumusan Islam dalam konteks sosio-budaya bangsa yang berbeda dengan pusat-pusat Islam di Timur Tengah. Kenyataan ini bukanlah peristiwa baru, melainkan berlangsung

${ }^{1}$ Dadang Kahmad, Sosiologi Agama (Bandung: Remaja Rosdakarya, 2000), h.172. 
semenjak awal masuknya agama yang diserukan Muhammad ini ke bumi Nusantara. ${ }^{2}$ Senada dengan pernyataan Quraish Shihab, Richard Bulliet pernah menyatakan hipotesisnya bahwa,"Sekarang waktunya untuk melihat Islam dari jendela Jakarta, Kuala Lumpur, atau Teheran, bukan lagi dari jendela Baghdad, Damaskus, atau Kairo.”3

Memperhatikan dua pernyataan di atas, yang secara substansi tidak jauh berbeda, maka timbul suatu fakta sosial bahwa keberadaan Islam dan umat Muslim di bumi Nusantara telah menjadi "ikon" yang memiliki kelebihan yang sangat unik dan spesifik bila dibandingkan dengan Islam dan umat Muslim di belahan Negara lainnya. Kemudian, hal ini telah menjadikan Islam di Nusantara menjadi kajian para Islamisis (orientalis) yang melihat adanya perkembangan serta pengaruh yang cukup signifikan dalam kesejarahan Islam di Nusantara ini.

Ada hal yang menarik ketika budaya disandingkan dengan agama, menurut St. Takdir Alisjahbana, bahwa budaya memiliki tiga nilai, yaitu nilai agama, seni dan solidaritas yang berkaitan dengan rasa dan bersendi pada perasaan, instuisi, dan imajinasi. Budaya ekspresif umumnya berwatak konservatif. Agama misalnya, jika tidak didukung oleh pemikiran yang rasional, ia mudah terjerumus ke dalam penghayatan serba mistik dan ghaib yang ekstrem dan irasional. Karena itu, yang utama bagi kemajuan umat manusia adalah bagaimana cara mengembangkan budaya yang memiliki keserasian nilai progresif dan ekspresif. ${ }^{4}$

Tulisan ini akan mencoba menguraikan tentang persentuhan agama Islam dengan kebudayaan asli Indonesia. Pembahasan lebih awal adalah menjelaskan tentang kebudayaan dan ruang lingkupnya, persentuhan agama Islam dengan kebudayaan asli masyarakat Indonesia.

\section{Kebudayaan dan Ruang Lingkupnya}

\section{Hakikat Kebudayaan}

Konsep awal tentang kebudayaan berasal dari E.B. Tylor yang mengemukakan bahwa culture atau civilization itu adalah complex whole includes knowledge, belief, art, morals, law, custom, and any other capabilities and habits acquired by man as a member of society. Batasan tentang kebudayaan ini mengemukakan aspek kebendaan dan bukan kebendaan

${ }^{2}$ M. Quraish Shihab,"Era Baru, Fatwa Baru" Kata Pengantar dalam MB. Hooker, Islam Mazhab Indonesia: Fatwa-Fatwa dan Perubahan Sosial, Cet. I (Jakarta: Teraju, 2002), h. 18.

${ }^{3}$ Richard Bulliet adalah Guru Besar Columbia University, New York. Pernyataan ini diperoleh dalam endorsement pada buku Menjadi Indonesia: 13 Abad Eksistensi Islam di Bumi Nusantara, sebuah karya yang menyajikan tentang keberadaan Islam di Nusantara dari pelbagai perspektif dan melibatkan cendikiawan-cendikiawan terbaik Indonesia. Karya ini diedit oleh Komarudin Hidayat dan Ahmad Gaus AF, diterbitkan oleh PT Mizan Media Utama.

${ }^{4}$ Simuh, Islam dan Pergumulan Budaya Jawa (Jakarta: Teraju, 2003), h. 3. 
itu sendiri atau materi dan nonmateri, sebagaimana Tylor kemukakan bahwa kebudayaan ialah keseluruhan kompleks yang meliputi pengetahuan, kepercayaan, kesenian, moral, hukum dan kemampuan-kemampuan lainnya serta kebiasaan yang diperoleh manusia sebagai anggota masyarakat. ${ }^{5}$

Kebudayaan adalah alat konseptual untuk melakukan penafsiran dan analisis ${ }^{6}$. Jadi keberadaan kebudayaan sangatlah penting, karena akan menunjang terhadap pembahasan mengenai eksistensi suatu masyarakat. Kebudayaan sebagai suatu sistem budaya, aktivitas dan hasil karya fisik manusia yang berada dalam suatu masyarakat di mana kemunculannya itu diperoleh melalui proses belajar, baik itu formal maupun informal. Hal ini menunjukan bahwa kebudayaan tidak akan hadir dengan sendirinya, melainkan ada karena adanya manusia dalam komunitas sosial, sehingga antara manusia, masyarakat dan kebudayaan akan saling mendukung. Manusia menciptakan kebudayaan sebagai usaha untuk mempertahankan hidupnya, karena dengan kebudayaan manusia akan mampu melaksanakan tugasnya di muka bumi ini sebagai khalifah. Dengan kebudayaan pula kehidupan keagamaan manusia akan nampak, dan ini menjadikan pembeda terhadap jenis makhluk lainnya.

Selanjutnya, Ralph Linton, mengajukan batasan kebudayaan yang lebih spesifik, menurutnya bahwa kebudayaan adalah " a culture is the configurationas of learned behavior and results of behavior whose components elements are shared and trasmistted by the members of a particular society". Pernyataannya ini mengandung makna bahwasannya kebudayaan atau budaya dianggap sebagai milik khas dari manusia, walaupun berbagai studi yang dilakukan kemudian tentang non human primate.

Sedangkan A.L. Kroeber mengganggap bahwa kebudayaan itu memiliki sifat yang superorganik yaitu keberadaannya telah mengatasi keberadaan dari setiap individu atau organik yang artinya walaupun kebudayaan itu dilakukan oleh semua orang, tetapi wujud atau keberadaannya bebas dari individu tertentu.

Dilihat secara peradaban Islam adalah terjemahan dari kata Arab al-hadharah alIslamiyyah. Di Indonesia, sebagaimana juga di Arab dan Barat, masih banyak orang yang mensinonimkan dua kata "kebudayaan" (Arab, al-tsaqafah; Inggris, cultur) dan "peradaban" (Arab, al-hadharah; inggris civilization). Dalam perkembangan antropologi sekarang, kedua istilah itu dibedakan. Kebudayaan adalah bentuk ungkapan tentang semangat mendalam suatu masayarakat. Sedangkan, manifestasi-manifestasi kemajuan mekanis dan teknologis lebih berkaitan dengan peradaban. Kalau kebudayaan lebih direflesikan

${ }^{5}$ Judistira K. Garna, Ilmu-Ilmu Sosial, Dasar-Konsep-Posisi (Bandung: Pascasarjana Unpad, 2001), h. 157.

${ }^{6}$ Ibid. 
dengan seni, sastra, religi (agama), dan moral, maka peradaban refleksi dalam politik, ekonomi dan teknologi. ${ }^{7}$

Dalam pengertian itulah yang dimaksud dengan peradaban Islam di sini adalah, Islam yang diwahyukan kepada Nabi Muhammad SAW. Telah membawa bangsa Arab yang semula terbelakang, bodoh tidak terkenal, dan diabaikan oleh bangsa-bangsa lain, menjadi bangsa yang maju. Ia dengan cepat menggerakan, mengembangkan dunia, membina satu kebudayaan dan peradaban yang sangat penting artinya dalam sejarah manusia hingga sekarang. Bahkan kemajuan Barat pada mulanya bersumber dari peradaban Islam yang masuk ke Eropa melalui Spanyol. Islam memang berbeda dari agama-agama lain. H.A.R. Gibb di dalam bukunya Whither Islam menyatakan, "Islam is indeed much more than a system of theology, it is a complete civilization" (Islam sesungguhnya lebih dari sekedar sebuah agama, ia adalah suatu peradaban yang sempurna). Karena yang menjadi pokok kekuatan dan sebab timbulnya kebudayaan adalah agama Islam, kebudayaan yang ditimbulkannya dinamakan kebudayaan atau peradaban Islam. ${ }^{8}$

\section{Unsur-Unsur Kebudayaan}

Kebudayaan setiap masyarakat atau suku bangsa terdiri atas unsur-unsur besar maupun unsur-unsur kecil yang merupakan bagian dari suatu kebulatan yang bersifat sebagai kesatuan. Ada beberapa unsur yang terdapat dalam kebudayaan, di mana kita sebut sebagai cultural universals, yang meliputi: peralatan dan perlengkapan hidup manusia, mata pencaharian hidup dan sistem-sistem ekonomi, sistem kemasyarakatan, bahasa (lisan dan tulisan), kesenian, sistem pengetahuan, religi (sistem kepercayaan). ${ }^{9}$

Selanjutnya, ketika memahami unsur-unsur kebudayaan tersebut, maka kita bisa mengetahui tentang terdapatnya unsur-unsur kebudayaan yang mudah berubah dan ada pula unsur-unsur kebudayaan yang susah berubah. Adapun unsur-unsur budaya yang mudah berubah meliputi; seni, bahasa, teknologi. Sedangkan unsur-unsur budaya yang sulit berubah meliputi: agama (sistem kepercayaan), sistem sosial, dan sistem pengetahuan.

Budaya juga dibedakan menjadi dua, yaitu budaya kecil (little culture), dan budaya besar (great culture). Budaya kecil adalah budaya yang berada pada suatu masyarakat yang lingkupnya kecil (dianut oleh beberapa orang saja) atau juga disebut local culture. Sedangkan budaya besar adalah budaya yang dianut oleh banyak orang dengan jumlah penganutnya yang luas. Ketika budaya kecil dan budaya besar saling berhubungan melalui proses asimilasi, maka kemungkinannya budaya kecil tersebut akan tersisihkan atau

${ }^{7}$ Badri Yatim, Sejarah Peradaban Islam; Dirasah Islamiyah II (Jakarta: PT. Raja Grafindo Persada, 2008), h. 1.

${ }^{8}$ Ibid., h. 2.

${ }^{9}$ Soerjono Soekanto, Sosiologi Suatu Pengantar (Jakarta: PT. Raja Grafindo Persada, 1990), h. 193. 
terkalahkan oleh budaya besar. Hal ini menunjukkan bahwa eksistensi dari budaya besar tersebut begitu kuat dan luas sehingga dengan mudah dan cepat bisa masuk kepada budaya kecil yang dianut oleh hanya bebera orang.

Budaya kecil atau budaya lokal yang ada pada suatu masyarakat merupakan budaya yang sudah dibangun sejak adanya umat manusia di muka bumi ini atau dengan kata lain, keberadaan budaya kecil sebagai bentuk dari keberhasilan umat manusia di dalam mempertahankan hidupnya, karena bagaimanapun juga budaya kecil itu ada secara turun temurun dari satu generasi ke generasi selanjutnya. Kehadiran budaya besar, tentunya akan membawa suatu perubahan yang akan terjadi pada suatu komunitas yang yang memiliki budaya kecil, sehingga keberadaan budaya besar akan tetap eksis dan bisa jadi keberadaan budaya kecil akan mengalami penyusutan atau bahkan hilang dari eksistensinya pada suatu masyarakat.

\section{Persentuhan Islam dengan Kebudayaan Asli Indonesia}

\section{Makna Agama Islam}

Islam berasal dari kata salam yang berarti "pasrah", "damai", "selamat". ${ }^{10}$ Kata Islam secara lengkap berasal dari kata aslama, yuslimu, islam, yang mempunyai beberapa arti, yaitu: (1) melepaskan diri dari segala penyakit lahir dan batin, (2) kedamaian dan keamanan, dan (3) ketaatan dan kepatuhan. ${ }^{11}$

Kata Islam disebut delapan kali dalam al-Qur'an, yaitu surah ali-Imran ayat 19 dan 85 , surah al-Maidah ayat 3 , surah al-An'am ayat 125 , surah az-Zumar ayat 22 , surah asSaf ayat 7, surah al-Hujarat ayat 17 , dan surah at-Taubah ayat 74. Islam merupakan agama samawi yang diturunkan oleh Allah SWT., melalui utusan-Nya Muhammad SAW. yang ajarannya terdapat dalam kitab suci al-Qur'an dan as-Sunah dalam bentuk perintahperintah, larangan-larangan, petunjuk-petunjuk untuk kebaikan manusia, baik di dunia maupun di akhirat. Lebih lanjut, Harun Nasution menyatakan bahwa Islam pada hakikatnya membawa ajaran-ajaran yang bukan hanya mengenai satu segi, tetapi mengenai berbagai aspek dari kehidupan manusia yang meliputi aspek akidah, ibadah, hukum, tasawuf, filsafat, politik dan pembaruan. ${ }^{12}$

Dari berbagai definisi yang ada Islam dikaitkan dengan keberagamaan seseorang, maka ada dua tipe makna al-Islam: ada Islam formal dan superficial (yang lahiriyah saja) dan menjadi motif sebagian agama yang tidak murni, dan ada Islam yang riil (al-

${ }^{10}$ Cyril Glasse, Ensiklopedi Islam (Jakarta: PT. RajaGrafindo Persada, 1999), h. 174.

${ }^{11}$ Tim Ichtiar Baru van Hoeve, Ensiklopedi Islam (Jakarta: Ichtiar Baru van Hoeve, 1994), h. 246.

${ }^{12}$ Ratu Suntiah dan Maslani, Sejarah Peradaban Islam (Bandung: CV. Insan Mandiri, 2010), h. 7-8. 
Islam al-Haq), yakni Islam yang sebenarnya. Kedua pengertian ini sesuai dengan firman Allah dalam Q.S. ali-Imran ayat 19. Dari uraian di atas dapat dilihat ada dua penekanan dalam merefleksikan makna al-Islam. Pertama, secara normatif mengandung makna penyerahan secara totalitas. Kedua, bermakna kedamaian dan keselamatan. Seseorang yang memeluk agama Islam, akan merasa damai dengan Tuhan dan damai dengan manusia. Damai dengan manusia akan terwujud setelah penyerahan kepada Tuhan. Penamaan agama dengan al-Islam menunjukan kepada hakikat dan esensi agama tersebut. Sikap pasrah pada Tuhan bukan hanya merupakan ajaran Tuhan kepada hamba-Nya, tetapi ia diajarkan oleh oleh-Nya dengan dikaitkan dengan alam manusia itu sendiri. Karena sikap pasrah tersebut tuntutan alami manusia, maka agama yang sah tidak bisa lain daripada sikap pasrah kepada Tuhan (al-Islam), yakni semua yang mengajarkan pasrah kepada sang Maha Pencipta, Tuhan yang Maha Esa. ${ }^{13}$ Jadi dalam realitas empirik, al-Islam menunjukan kepada suatu agama yang dibawa oleh Nabi Muhammad.

Islam adalah nama dari agama wahyu yang diturunkan Allah SWT. Kepada Rasulrasul-Nya untuk disampaikan kepada manusia. Agama Islam berisi ajaran-ajaran Allah yang mengatur hubungan manusia dengan Allah, manusia dengan manusia, dan manusia dengan alam. Islam dalam pengertian ini adalah agama yang dibawa oleh para Rasul Allah, sejak nabi Adam sampai Nabi Muhammad SAW. Islam yang diturunkan kepada Nabi Muhammad adalah wahyu Allah terakhir untuk manusia. Oleh karena itu, agama ini sudah sempurna dan senantiasa sesuai dengan tingkat perkembangan manusia sejak masa diturunkannya, empat belas abad yang lalu hingga akhir peradaban manusia. ${ }^{14}$

Islam diturunkan sebagai pedoman agar manusia dapat menentukan mana yang baik dan mana yang buruk serta yang hak dan yang batil. Sejak awal penciptaan manusia, Allah SWT. telah menurunkan agama pada manusia, yang dibawa oleh seorang rasul pada setiap masa tertentu dan untuk bangsa tertentu. Hal itu terus berlangsung sampai datang Muhammad SAW., nabi dan rasul terakhir yang diutus membawa agama bagi seluruh umat manusia dan berlaku untuk sepanjang zaman. ${ }^{15}$

Sebagai agama yang melengkapi proses kesinambungan wahyu. Islam memiliki tujuh karakteristik ajaran. Pertama, ajarannya sederhana, rasional dan praktis. Islam adalah agama tanpa mitologi. Islam membangkitkan kemampuan berpikir dan mendorong manusia untuk menggunakan penalarannya (Q.S. 39: 9, Q.S. 6: 98, Q.S. 2: 269). Di samping itu, Islam tidak mengizinkan penganutnya berpikir dengan teori kosong, tetapi diarahkan pada pemikiran yang aplikatif (QS. 13: 3). Kedua, kesatuan antara kebendaan dan keruhanian. Islam tidak membagi kehidupan atas dua bagian, yaitu material dan spiritual. Menurut

${ }^{13}$ Ajat Sudrajat, Tafsir Inklusif; Makna Islam (Yogyakarta: AK. Group, 2004), h. 11-12.

${ }^{14}$ Toto Suryana, Cecep Alba, E. Syamsudin dan Udji Asiyah, Pendidikan Agama Islam, (Bandung: Tiga Mutiara, 2007), h. 30.

${ }^{15}$ Tim Ichtiar Baru van Hoeve, Ensiklopedi Islam, h. 247. 
pandangan Islam, kemajuan spiritual hanya dapat dicapai bila manusia berada di tengah manusia lain di dunia dan keselamatan spiritual baru dapat dicapai dengan memanfaatkan sumber daya material. ${ }^{16}$

Ketiga, Islam memberi petunjuk bagi seluruh segi kehidupan manusia meskipun sebagian petunjuk bersifat umum (Q.S. 2: 208). Keempat, keseimbangan antara individu dan masyarakat. Islam mengakui keberadaan manusia sebagai individu dan menganggap setiap orang memiliki tanggung jawab pribadi kepada Tuhan, bahkan Islam menjamin hak-hak asasi individu dan tidak mengizinkan adanya campur tangan orang lain di dalamnya (Q.S. 53: 39). Namun di lain pihak, Islam mengembangkan rasa tanggung jawab sosial dalam diri manusia dan menyerukan individu-individu untuk memberi andil dalam membina kesejahteraan masyarakat (Q.S. 51: 19). Kelima, keuniversalan dan kemanusiaan. Islam ditujukkan untuk seluruh umat manusia. Tuhan dalam Islam adalah Tuhan sekalian alam (Q.S. 1: 2) dan Muhammad SAW. adalah rasul Tuhan untuk seluruh umat manusia (Q.S. 7: 158 dan Q.S. 21: 107). Dalam Islam, seluruh umat manusia adalah sama, apa pun warna kulit, bahasa, ras atau kebangsaannya. ${ }^{17}$

Keenam, ketetapan dan perubahan. al-Qur'an dan sunah yang berisi pedoman abadi dari Tuhan tidak terikat oleh batasan ruang dan waktu, bersifat abadi. Namun pedoman tersebut sering kali bersifat umum atau secara garis besar, sehingga memberikan kebebasan pada manusia untuk berijtihad dan mengaplikasikannya pada setiap kondisi masyarakat. Ketujuh, al-Qur'an sebagai pedoman suci umat Islam yang telah berumur sekitar lima belas abad, tetapi terjamin kesucian dan kemurniannya. ${ }^{18}$

Agama adalah sistem kepercayaan (iman) yang diwujudkan dalam sistem perilaku sosial para pemeluknya. Ia berkaitan dengan pengalaman manusia, baik sebagai individu maupun kelompok sehingga setiap perilaku yang diperankannya akan terkait dengan sistem keyakinan dari ajaran agama yang dianutnya. Perilaku individu dan sosial digerakkan oleh kekuatan dari dalam yang didasarkan pada nilai-nilai ajaran agama yang menginternalisasi sebelumnya. Oleh karena itu, keagamaan yang bersifat subjektif, dapat diobjektifkan dalam pelbagai macam ungkapan, dan ungkapan-ungkapan tersebut memiliki struktur tertentu yang dapat dipahami. ${ }^{19}$

Begitu pun dengan agama Islam yang berisi tentang sistem kepercayaaan/iman yang diwujudkan dalam sistem perilaku sosial para pemeluknya. Ia berkaitan dengan pengalaman manusia baik sebagai individu maupun kelompok sehingga setiap perilaku yang diperankannya akan terkait dengan sistem keyakinan dari ajaran agama yang dianutnya. Islam

${ }^{16}$ Ibid.

${ }^{17}$ Ibid.

${ }^{18}$ Ibid.

${ }^{19}$ Dadang Kahmad, "Agama Islam dalam Perkembangan Budaya Sunda", dalam Cik Hasan Bisri, et.al., Pergumulan Islam dan Kebudayaan di Tatar Sunda (Bandung: Kaki Langit, 2005), h. 68. 
adalah agama yang berkarakteristikkan universal, dengan pandangan hidup mengenai persamaan, keadilan, kebebasan dan kehormatan serta memiliki konsep teosentrisme yang humanistik sebagai nilai inti (core value) dari seluruh ajaran Islam. ${ }^{20}$

\section{Agama Islam sebagai Sistem Nilai dan Simbol}

Al-Qur'an dalam surah al-Baqarah ayat 148 mengakui bahwa masyarakat terdiri atas berbagai macam komunitas yang memiliki orientasi kehidupan sendiri-sendiri. Manusia harus menerima kenyataan keragaman budaya dan agama serta memberikan toleransi kepada masing-masing komunitas dalam menjalankan ibadahnya. Oleh karena itu kecurigaan tentang sifat Islam yang antiplural, sangatlah tidak beralasan dari segi ideologis. Bila setiap muslim memahami secara mendalam etika pluralitas yang terdapat dalam al-Qur'an, tidak perlu lagi ada ketegangan, permusuhan dan konflik dengan agama-agama lain, selama mereka tidak saling memaksakan. ${ }^{21}$

Selanjutnya di dalam Islam kita mengenal adanya konsep tauhid, suatu konsep sentral yang berisi ajaran bahwa Tuhan adalah pusat dari segala sesuatu, dan bahwa manusia harus mengabdikan diri sepenuhnya kepada-Nya. Konsep tauhid ini mengandung implikasi doktrinal lebih jauh bahwa tujuan kehidupan menusia tak lain kecuali menyembah kepadaNya. Doktrin bahwa hidup harus diorientasikan untuk pengabdian kepada Allah. Inilah merupakan kunci dari seluruh ajaran Islam. Dengan kata lain, di dalam Islam, konsep mengenai kehidupan berpusat kepada Tuhan. Sistem nilai tauhid mendasarkan diri pada pandangan semacam ini. ${ }^{22}$

Menurut Islam, manusia harus memusatkan diri kepada Tuhan, tetapi tujuannya adalah untuk kepentingan manusia sendiri, atau disebut sebagai humanisme teosentris yang merupakan nilai inti dari seluruh ajaran Islam. Dari tema inilah muncul sistem simbol, sistem yang terbentuk karena proses dialektik antara nilai dan kebudayaan. Misalnya dalam al-Qur'an, kita mengenal adanya rumusan amr ma'ruf nahyi munkar, yaitu perintah untuk menyeru kepada kebajikan dan mencegah kemungkaran. Dari rumusan itu kita bisa melihat adanya dua proses yang sekaligus berlawanan tetapi sekaligus merupakan satu kesatuan: emansipasi dan pembebasan. Dalam konteks ini seluruh sistem simbol yang muncul dari rumusan amr ma'ruf nahyi munkar ditujukan untuk serangkaian gerakan pembebasan dan emansipasi. Nahyi munkar, atau mencegah kemunkaran berarti membebaskan manusia dari semua bentuk kegelapan(zhulmat) dalam berbagai manifestasinya. Dalam bahasa ilmu sosial ini juga berarti pembebasan dari kebodohan, kemiskinan, ataupun penindasan. Sementara, amr ma'ruf yang merupakan langkah berangkai dari

\footnotetext{
${ }^{20}$ Kuntowijoyo, Paradigma Islam,Interpretasi untuk Aksi (Bandung: Mizan, 1991), h. 229.

${ }^{21}$ Ibid., h. 173.

22Ibid., h. 229.
} 
gerakan nahyi munkar, diarahkan untuk mengemansipasikan manusia kepada amr, kepada cahaya petunjuk Ilahi, untuk mencapai keadaan fitrah. Fitrah adalah keadaan di mana manusia mendapatkan posisinya sebagai mahkluk yang mulia. ${ }^{23}$

Dari nilai inti humanisme teosentris, Islam telah menginspirasikan lahirnya gerakan pembebasan dan emansipasi. Tapi kendatipun demikian, gerakan pembebasan dan emansipasi ini sesungguhnya juga tumbuh dari suatu prinsip dialektis lain yang disebut tazkiyah. Tazkiyah adalah usaha rasional manusia beriman yang berorientasi filosofisnya adalah humanisme teosentris untuk selalu membersihkan diri atau meningkatkan kualitas ruhaninya secara terus menerus. Demikian pula dengan ekspresi simbolis dari karya-karya Muslim, seperti kesenian, kesusastraan dan hasil-hasil budaya lainnya, pada dasarnya juga mencerminkan pelaksanaan nilai-nilai sentral Islam itu melalui prinsip tazkiyah. ${ }^{24}$

Islam menjadi nilai sangat penting bagi wilayah pengembangan kebudayaan, Islam bisa dilihat dari sejarah maju mundurnya pada masa pembaharuan dalam sejarah, Islam sangatlah menjadi titik utama bagi pengkajian-pengkaji kebudayaan dalam Islam. Kebudayaan sering dikaitkan dengan adanya sejarah Islam yang berada di wilayah tempat tersebut. Karena para pengembang Islam lari ke wilayah-wilayah yang diperlukan umat Islam untuk lebih maju, dan tidak mengabaikan budaya yang sedang berada di wilayah tersebut.

Maju mundurnya umat Islam dalam tataran historis sebagaimana telah disebut pembaharuan dalam Islam yang disebut modern dan mempunyai tujuan untuk membawa umat Islam kepada kemajuan sebelum masuk ke dalam pokok masalah, ada baiknya diuraikan terlebih dulu sejarah Islam secara ringkas, bukan hanya untuk mengetahui waktu mulanya periode Modern itu, tetapi juga untuk melihat perkembangan maju mundurnya umat Islam yang terjadi dalam sejarah peradaban. Jika dilihat dari masa periode sejarah Islam, dapat dibagi ke dalam tiga periode besar yaitu: klasik, pertengahan dan modern. ${ }^{25}$

Islam merupakan agama yang hidup dalam sebagian besar masyarakat Indonesia. Bukan itu saja, Islam adalah satu ideologi. Islam bukan semata-mata satu agama dalam arti hubungan manusia dengan Tuhan (habluminallah). Islam mengandung dua unsur. Unsur hubungan manusia dengan Tuhan-Nya, dan unsur hubungan manusia dengan sesama makhluk. Unsur ibadah dan muamalah. Islam mempunyai kaidah, mengenai soal ibadah, yakni hubungan manusia dengan Tuhan, semua dilarang kecuali yang diperintahkan. Islam memberikan dasar-dasar untuk mengatur hidup keduniaan yang bersifat abadi. ${ }^{26}$

Islam jika dilihat secara sejarah sejak kelahirannya, tersimpul dalam sabda Nabi Muhammad SAW., "Aku diutus oleh Allah untuk menyempurnakan nilai-nilai akhlak yang

${ }^{23}$ Ibid., h. 229.

${ }^{24}$ Ibid., h. 229-230.

${ }^{25}$ Harun Nasution, Pembaharuan Dalam Islam; Sejarah Pemikiran dan Gerakan (Jakarta: PT. Bulan Bintang, 2003), h. 4.

${ }^{26}$ Mohammad Nasir, Islam Sebagai Dasar Negara (Bandung: SEGAR ARSY, 2004), h. 60. 
baik." Maka jika Islam menjadi dasar negara, dengan sendirinya ia akan segera melihat dan memeriksa apa nilai-nilai yang sudah ada dalam masyarakat. Islam datang dengan teguran al-Qur'an, "Janganlah kamu bertolong-tolongan atas dosa dan bermusuh-musuhan." Islam mengatur nilai dalam tatanan hidup bagi manusia dengan nilai demokrasi atau musyawarah. ${ }^{27}$ Islam hanyalah salah satu sekian mata rantai peradaban umat manusia. Oleh karena itulah, sumbangan Islam harus diberikan dalam kerangka kebersamaan dengan semua pihak, bukan menyendiri di luar sejarah. Islam memperlihatkan pertalian dengan pandangan hidup lainnya dalam tatanan universal.

Sejarah Islam merupakan masa berkembangnya pemikiran yang paling subur yang paling pernah dilalui alam pikiran budaya manusia. Ia melahirkan pemikiran di segala bidang pemikiran budaya yang masa kini masih tetap hidup dan berkembang memengaruhi alam pikiran sikap dan perilaku umat Islam. Islam bukan hanya pencipta perkembangan politik, ekonomi sosial yang luar biasa dalam sejarah, tetapi juga pencipta alam pikiran keilmuan dan filsafat. Ia melahirkan dan mengembangkan pemikiran keagamaan yang berdasarkan wahyu, juga pemikiran yang berkaitan dengan filsafat dan ilmu pengetahuan kemanusiaan pada umumnya. Jadi budaya Islam di samping mengembangkan pemikiran agama, juga mengembangkan segala aspek pemikiran kemanusiaan yang menghidupkan dan memberikan fasilitas pada warisan sebelum Islam. ${ }^{28}$

Islam lahir di Semenanjung Arabia pada abad ke-6 Masehi. Pada awal kehadirannya, ia mengalami hambatan kultur sebab lahir di tengah masyarakat nomaden dan tidak berperadaban (vacuum cultural). Dalam perkembangan selanjutnya, penyebaran telah menakjubkan para ahli sejarah. Sebab, dalam jangka yang relatif pendek Islam telah dianut oleh penduduk yang mendiami setengah wilayah dunia. Oleh karena itu, sebagai sistem ajaran keagamaan yang lengkap, Islam memberi tempat pada dua jenis penghayatan keagamaan. Pertama, eksoterik (zahiri), yaitu penghayatan keagaman yang berorientasi pada formalitas atau pada norma dan aturan-aturan keagamaan yang ketat. Kedua, esoterik (bathini), yaitu penghayatan keagamaan yang berorientasi dan menitikberatkan pada inti keberagamaan dan tujuan beragama. ${ }^{29}$

Islam diakui sebagai agama yang ajarannya mengandung muatan universal, yang mencakup sebagai dimensi, baik dimensi-dimensi lainnya. Karena keuniversalitasannya tersebut, ketika berbicara soal aliran Islam dan wacana sosial, kerapkali kita berjumpa dengan pembicaraan tentang bagaimana universalitas Islam tersebut dapat ditransformasi-

${ }^{27}$ Ibid., h. 62-63.

${ }^{28}$ H. A. Hidayat, Pemikiran Islam; Tentang Teologi dan Filsafat (Bandung: Pustaka Setia, 2006), h. 109-110.

${ }^{29}$ Dadang Kahmad, Tarekat Dalam Islam: Spiritualitas Masyarakat Modern (Bandung: Pustaka Setia, 2002), h. 63-64. 
kan dalam kehidupan manusia. Berbagai format alternatif pun kemudian dimunculkan oleh para pemikir muslim. ${ }^{30}$

\section{Kebudayaan Asli Masyarakat Indonesia}

Suku-suku bangsa Indonesia, khususnya suku Jawa sebelum kedatangan pengaruh Hinduisme telah hidup teratur dengan animisme-dinamisme sebagai akar religiositasnya, dan hukum adat sebagai pranata sosial mereka. Adanya warisan hukum adat menunjukkan bahwa nenek moyang suku bangsa Indonesia asli telah hidup teratur di bawah pemerintahan atau kepala adat, walaupun masih dalam bentuk yang sangat sederhana. Religi animismedinamisme yang menjadi akar budaya asli Indonesia-khususnya masyarakat Jawa- cukup memiliki daya tahan yang kuat terhadap pengaruh kebudayaan-kebudayaan yang telah berkembang maju. Keadaan ini memancing timbulnya teori kekenyalan dan ketegaran kebudayaan asli pribumi Indonesia. ${ }^{31}$ R.M. Suctipto Wirjosuparto mengatakan sebagai berikut:

Sesungguhnya kebudayaan Indonesia (asli) menjalin hubungan dengan kebudayaankebudayaan lain yang kebanyakan dipandang telah mengalami perkembangan yang lebih tinggi-misalnya kebudayaan Hindu, Islam, dan Barat-yang mengakibatkan termodifikasinya kebudayaan Indonesia di dalam proses yang memungkinkannya mempertahankan karakter ke-Indonesiaan-nya, bahkan dalam hubungan dengan kebudayaan asing itu pola ke-Indonesiaan-nya tetap sama, lantaran unsur-unsur kebudayaan asing itu terserap dalam pola ke-Indonesia-an. ${ }^{32}$

Kepercayaan animisme dalam arti luas dimaksudkan setiap andalan akan adanya unsur rohani (anima-jiwa, nyawa, semangat, tondi, begu, ganan, amirue dan sebagainya) di samping unsur jasmani atau madi, entah di dalam, entah di luar manusia. Dalam arti lebih khusus animisme menunjukkan kepercayaan akan roh-roh halus yang beridiri lepas dari manusia dan campur dalam urusan insani. Fakta kepercayaan orang akan roh-roh tersebut belum membenarkan teori animisme dari Tylor dan kawan-kawan, bahwa semua agama berasal dari evolusi kepercayaan itu. Animisme terutama tersebar di antara golongan penduduk yang hidup dari pertanian. Animisme seringkali sejajar dengan kepercayaan kepada Tuhan Yang Maha Esa, tetapi Dia sudah hilang dari perhatian manusia sehingga diganti oleh makhluk-Nya. Animisme mengisi kekosongan iman ketuhan dengan mengkhayalkan dewa-dewi dan roh perantara. Biasanya dibedakan antara mereka yang membantu h. 169.

${ }^{30}$ Muhtar Solihin, Prinsip-prinsip Dasar Pemikiran Keislaman (Bandung: Pustaka Setia, 2003),

${ }^{31}$ Simuh, Islam dan Pergumulan Budaya Jawa (Jakarta: Teraju, 2003), h. 40.

${ }^{32}$ Ibid. 
dan mereka yang memusuhi dan mengganggu manusia. Jenis kedua harus dilembutkan hatinya dengan sesaji, mantera, makanan atau bunga. ${ }^{33}$

Elastisitas sifat kebudayaan Indonesialah yang mampu mempertahankan ciri keIndonesiaan-nya. Bahkan kesimpulan yang lebih menarik diketengahkan J.W.M. Bakker dalam kajiannya yang berjudul, Agama Asli Indonesia. Beliau menyimpulkan bahwa, "Walaupun bagian terbesar orang Indonesia mengaku beragama Islam, namun sikap keagamaan sehari-hari yang mereka hayati,"dijiwai dalam batinnya oleh agama asli Indonesia yang kaya raya isinya, yang dipelihara dengan khusuk, yang tidak mau 'dirombak' oleh agama asing." Mengapa demikian? Menurut J.W.M. Bakker alasan mengapa Islam tidak berakar dalam jiwa orang Indonesia asli karena,"Belum adanya evaluasi teologis Muslim terhadap keruhanian agama-agama lain”.

Ciri khas religi animisme-dinamisme adalah menganut kepercayaan roh dan daya gaib yang bersifat aktif. Prinsip roh aktif menurut kepercayaan animisme adalah bahwa roh orang mati tetap hidup dan bahkan menjadi sakti seperti dewa, bisa mencelakakan atau mensejahterakan masyarakat manusia. Dunia ini juga dihuni oleh berbagai macam roh gaib yang bisa membantu atau mengganggu kehidupan manusia. Seluruh ritus atau meditasi religi animisme-dinamisme dimaksudkan untuk berhubungan dan memengaruhi roh dan kekuatan gaib tersebut, bahkan melalui meditasi atau dukun prewangan dijalin hubungan langsung untuk minta bantuan dengan roh dan kekuatan gaib itu. ${ }^{34}$

Religi animisme-dinamisme tentu menumbuhkan kelompok pawang yang berfungsi sebagai pendeta, perantara, dukun, atau orang tua yang bisa berhubungan langsung dengan segala roh yang menguasai kekuatan gaib. Religi animisme-dinamisme memuncak melalui pengembangan perdukunan, klenik dengan rumusan lafal yang dipercayai berdaya magis. ${ }^{35}$

Masalahnya bagi umat Islam, kepercayaan akan adanya ruh dan daya gaib aktif ini, sangat bertentangan dengan Islam. Hadis Nabi SAW., menegaskan bahwa bila anak Adam meninggal dunia putuslah segala amalnya. Tak ada manusia yang bisa beramal lagi. Inilah yang dimaksud dengan istilah roh pasif. Prinsip tauhid menegaskan, bahwa ruh manusia di alam kubur mulai merasakan penderitaan jika amalnya di dunia buruk; sebaliknya, merasakan nikmat jika amalnya baik. Islam membebaskan umatnya dari segala bentuk kepercayaan roh dan tenaga gaib yang menyekutukan Kekuasaan Allah SWT. Islam memang membutuhkan dukungan cara berpikir rasional dan ilmiah. ${ }^{36}$

\footnotetext{
h.76-77.

${ }^{34}$ Ibid, h. 41.

${ }^{35}$ Ibid.

${ }^{36}$ Ibid, h. 42.
}

${ }^{33}$ Rachmat Subagya, Agama Asli Indonesia (Jakarta: Yayasan Cipta Loka Caraka, 1981), 


\section{Persentuhan Islam dengan Kebudayaan Asli Indonesia}

Berdasarkan hasil pengkajian penulis terhadap tema variasi agama dengan kebudayaan lokal di Indonesia atau pun terkait hubungan Islam dengan kebudayaan lokal pada masyarakat Indonesia, pada umumnya mengambil bentuk integrasi dalam beragam pola. Nur Syam ${ }^{37}$ mengelompokkan bentuk integrasi tersebut ke dalam dua pola, yaitu: pertama, pola hubungan yang bercorak sinkretik ${ }^{38}$, kedua pola hubungan yang bercorak akulturatif. ${ }^{39}$ Juga terdapat pola hubungan yang lain yaitu pola hubungan bercorak kolaboratif ${ }^{40}$, dan pola hubungan yang bercorak legitimasi ${ }^{41}$. Di samping beberapa corak tersebut, bisa jadi masih ada lagi pola hubungan agama dan kebudayaan dalam corak lainnya.

Di antara banyak kajian tentang corak hubungan agama dengan kebudayaan lokal, karya monumental dihasilkan pada tahun 1960 oleh Clifford Geertz dalam "The Religion of Java"42. Karya Geertz ini adalah studi partikular tentang kepercayaan, simbol, ritual dan adat kebiasaan yang terdapat pada suatu suku bangsa yang sangat dikenalnya, yakni Jawa, melalui penyelamannya ke dalam bahasa dan kebudayaan suku itu. Studi tersebut menjelajahi secara rinci keterjalinan yang kompleks antara tradisi keagamaan Islam, Hindu, dan Animisme penduduk lokal yang memengaruhi setiap pojok dan celah kehidupan masyarakat Jawa. Studi pertama Geertz ini telah menjadi sumber inspirasi bagi sebagian besar ide-idenya. Sehingga ia berkesimpulan, jika klaim para fungsionalis mengatakan bahwa agama selalu dibentuk oleh masyarakatnya, maka adalah benar pula bahwa masyarakat juga dibentuk oleh agamanya.

Setelah Geertz, banyak peneliti lain yang tertarik mengkaji tema Islam dan multikulturalisme di Indonesia. Paul Stange memiliki “Gerakan Sumarah dalam Mistisisme

${ }^{37}$ Nur Syam adalah dosen di IAIN Sunan Ampel Surabaya menyelesaikan program doktornya dari Universitas Airlangga Surabaya dengan disertasi berjudul Tradisi Islam Lokal Pesisir: Studi Konstruksi Sosial Upacara pada Masyarakat Pesisir Palang Tuban Jawa Timur (2003). Dalam penelitian tersebut diungkapkan tentang adanya pola hubungan yang bercorak kolaboratif, yakni tradisi Islam lokal hasil kolaborasi berbagai penggolongan sosial yang ada di antara mereka. Nur Syam, Islam Pesisir (Yogyakarta: LKiS, 2004), h. vii.

${ }^{38}$ Sinkretik yang penulis maksud adalah bertemunya satu kebudayaan masyarakat dengan unsur agama atau kepercayaan lainnya yang melekat pada kebudayaan suatu masyarakat. Deni Miharja, Integrasi Agama Islam dengan Kebudayaan Sunda (Disertasi, Pascasarjana UIN SGD Bandung, 2013), h.14-16.

${ }^{39}$ Akulturatif yang dimaksud penulis adalah bertemunya dua kebudayaan pada suatu masyarakat yang tidak menghilangkan salah satu unsur kebudayaan, melainkan keduanya berbaur dan masih tetap mununjukkan ciri dari kedua kebudayaan tersebut.

${ }^{40}$ Kolaboratif yang dimaksud adalah bertemunya dua atau lebih unsur kebudayaan yang secara bersama-sama ada pada sebuah tradisi masyarakat.

${ }^{41}$ Legitimasi yang dimaksud adalah upaya membenarkan suatu kebudayaan masyarakat dengan kebenaran agama yang diambil dari nash al-Qur'an atau hadis.

${ }^{42}$ Clifford Geertz, The Religion of Java (Glencoe: The Free Press, 1960), h. 18. 
Jawa" pada tahun $1980 .{ }^{43}$ Simuh pada tahun 1987 mengkaji tentang "Aspek Mistik Islam Kejawen dari naskah Wirid Hidayat Jati. ${ }^{44}$ Mark R. Woodward kembali meneliti Islam di Jawa dengan fokus kesalehan normatif dan mistisisme dan kesultanan Yogyakarta pada tahun 1989. ${ }^{45}$ Martin Van Bruinessen pada tahun 1992 telah meneliti Tarekat Naqsabandiah di Indonesia. ${ }^{46}$ Pada tahun 1999, Andrew Beatty kembali melakukan penelitian tentang Islam Jawa. ${ }^{47}$ Menurut Robert Hefiner, karya Beatty ini menyajikan pembahasan seimbang dan berhasil menangkap tekstur sosial dan tujuan moral dari beragam variasi agama yang berbeda-beda itu secara lebih baik ketimbang buku-buku lain setelah The Religion of Java karya Geertz. Menurutnya, ini adalah karya luar biasa di bidang antropologi.

Dalam kesempatan ini, ada baiknya jika karya Andrew Beatty tentang variasi agama di Jawa ditelaah lebih lanjut, menimbang karya ini terbilang karya yang paling mutakhir tentang variasi agama di Jawa. Ini adalah karya mengenai agama di Jawa: aneka ragam bentuk, kontroversi dan rekonsiliasinya. Lebih abstrak lagi, tulisan ini adalah mengenai perbedaan dan sinkretisme kebudayaan. Ketika antropologi begitu sarat dengan cara berfikir kemajemukan budaya di Barat, dengan tantangan terhadap identitas pribadi, toleransi bersama dan harmoni sosial yang dihadirkannya, maka Jawa menjadi contoh dari masyarakat tradisional yang mempresentasikan hal itu. Dengan mengkaji proses saling memengaruhi antara ketaatan islami, mistisisme, hinduisme dan tradisi lama, serta memahami kompromi-kompromi fakta keanekaragaman itu, penulisnya berharap dapat menyajikan suatu pendekatan yang dinamik dan absah mengenai bagaimana agama "bekerja" dalam suatu masyarakat kompleks.

Banyuwangi, suatu kota di penghujung Timur pulau Jawa dipandang paling layak untuk memberikan gambaran tentang fenomena di atas. Di pedesaan Banyuwangi, secara khas ditemukan pertemuan yang selaras antara mistisisme, panteisme, pemujaan roh halus dan ketaatan agama normatif dalam sebuah kerangka sosial. Namun, lapangan penelitian, baik di perkotaan maupun di daerah terpencil, ditandai oleh hubungan yang longgar dan kerap kali paradoks antara bentuk-bentuk agama dan realitas sosial. Sehingga, kita berhadapan dengan diversitas, inkonsistensi, elektisisme dan bahkan ketidaklogisan.

Persoalan "variasi lokal" adalah intrinsik bagi "peradaban tardisional", oleh karena itu seharusnya menjadi objek penelitian dan bukanlah dianggap sebagai kesukaran

${ }^{43}$ Paul Stange, The Sumarah Movement In Javanese Myticis (Unpublished PhD. Thesis, Universitas Of Wisconsin-Madison, 1980), h. 18.

${ }^{44}$ Simuh, "Aspek Mistik Islam Kejawen Dalam 'Wirid Hidayat Jati”, dalam Ahmad Rifa'i Hasan (ed.), Warisan Intelektual Islam Indonesia (Bandung: Mizan, 1987), h. 1.

${ }^{45}$ Mark R. Woodward, Islam in Java (Universitas of Arizona Press, 1989), h. 1.

${ }^{46}$ Martin van Bruinessen, Tarekat Naksabandiyyah di indonesia (Bandung,: Mizan, 1992)., h. 1.

${ }^{47}$ Andrew Beatty, dalam Varieties of Javanese Religion, Alih Bahasa Achmad Fedyani Saefudin, (Jakarta: RajaGrafindo Persada, 2001), h. 19. 
semata-mata. Gambaran variasi lokal di Jawa adalah keteraturan yang dibangun dengan tekun, harmonisasi dan berstruktur mantap - suatu struktur yang rumit dan luwes yang dibangun di atas riwayat kekasaran dan ketidakteraturan. Di Jawa, tradisi tertentu, - mistisisme, Islam dan hinduisme - mengalami hibridisasi satu sama lain, masuk lebih jauh dari wacana ritual dan keagamaan; dan hakikat dari kombinasi yang lebih tinggi ini selanjutnya memengaruhi beberapa institusi dari ketiga unsur tradisi itu. Kalapun terjadi sinkretisme pada ketiga unsur tradisi itu, maka sinkretisme tersebut dalam arti suatu proses dinamik dan berulang, suatu faktor yang konstan dalam reproduksi kebudayaan, bukan hasil yang statis. Sinkretisme di sini mengarahkan kita pada isu "akomodasi, kontestasi, kelayakan, indigenisasi dan wadah bagi proses antar budaya yang dinamik".

Dalam karya ini, penulisnya berupaya berbicara dalam wacana tengah antara prespektif 'individu sedang bertindak" dan kerangka "sosiosentrik-reduktif'. Ketimbang memusatkan perhatian pada kejadian-kejadian (events) belaka atau paradigma interpretatif belaka. Pendekatan dalam tulisan ini adalah apa yang terjadi pada "tuan rumah" kita dan bagaimana mereka memandang kejadaan-kejadian itu. Jadi, pokok sentralnya adalah bagaimana gagasan-gagasan itu muncul, kemudian diterima dan memperoleh penguatan di antara orang-orang yang bersangkutan.

Laporan penelitian Andrew Beatty yang telah dibukukan itu, disusun dalam sistematika sebagai berikut. Setelah pendahuluan, penulisnya membahas tentang slametan, suatu ritual makan yang formatnya - secara ideal - melintasi semua varian agama yang dibicarakan pada bab selanjutnya. Selanjutnya, ia berbicara tentang tempat keramat dan tentang barong, suatu drama populer di mana pelakunya kerasukan roh halus penjaga desa. Bab berikutnya, Beatty membahas berbagai cara kompromi orang Jawa dengan Islam dan negara modern. Disambung dengan kajian Islam praktis, yakni Islam sebagaimana dikonsepsikan dan dipraktikkan dalam realitas sosial. Selanjutnya, Ia membahas khusus mengenai kejawen, suatu pembahasan tentang mistisisme Jawa. Lalu bab berikutnya menguraikan sektesekte mistikal di pedesaan Banyuwangi. Dalam bab terakhir dibahas tentang Hindu Jawa, membahas fenomena sinkretisme pada sebuah desa yang penduduknya campuran Muslim dan Hindu di selatan Banyuwangi. Dalam kesimpulan Beatty menegaskan bahwa, variasi agama Jawa memiliki nuansa kompleksitas dan saling keterkaitan yang erat antara unsur Islam, Hinduisme dan mistisisme lokal yang dipakai orang Jawa sebagai landasan pemecahan masalah-masalah peredaan kultural. Yang membuat unsur-unsur tersebut dapat terjalin bersama adalah konteks sosial yang sama, di mana tak ada satu pun unsur yang dapat dipahami tanpa referensi dari unsur yang lain. Meskipun ini adalah pandangan strukturalis, namun menurut Beatty ini membawa kita keluar dari sekedar formalitas simbol-simbol. Karena sebagaiman diketahui, kompleksitas ekspresi budaya terikat kuat dengan eksigensi kehidupan desa Jawa: kebutuhan akan rukun, posisi Islam yang memperoleh previlese, campur tangan kekuasaan negara dan ancaman laten chaos.

Sesuai dengan karakteristik penelitian antropologi yang naturalistik, kesimpulan 
Beatty itu mungkin benar dalam konteks Banyuwangi, itu pun jika disepakati istilah Jawa yang dimaksud adalah Jawa dalam terminologi budaya, bukan terminologi regional atau administrasi politik, misalnya. Sayangnya Beatty tidak secara eksplisit memberikan definisi tentang Jawa sebelumnya. Ia hanya mengatakan, tulisan ini (agama jawa) adalah mengenai keanekaragaman dan sinkretisme, dengan mengabaikan pola interelasi lain yang bisa saja terjadi antara agama dan budaya di Jawa. Naluri dalam konteks kekinian sangat mungkin bisa terjadi interelasi agama dan budaya dalam pola yang berbeda, seperti deferensiasi, kontekstualisasi, pribumisasi atau yang lainnya. Terlebih lagi jika Beatty punya kesempatan dan kearifan untuk "melirik" ke bagian Barat pulau Jawa yaitu Jawa Barat.

Agama Islam sejak kehadiranya di muka bumi ini, telah memainkan peranannya sebagai salah satu agama yang menjadi rahmat bagi semesta alam. Ini, tentunya membawa Islam sebagai bentuk ajaran agama yang mampu mengayomi keberagaman umat manusia dimuka bumi ini. Islam sebagai agama universal sangat menghargai kebudayaan yang ada pada suatu masyarakat, sehingga kehadiran Islam di tengah-tengah masyarakat tidak bertentangan, melainkan Islam dekat dengan kehidupan masyarakat, di sinilah sebenarnya, bagaimana Islam mampu membuktikan dirinya sebagai ajaran yang lentur di dalam memahami kondisi kehidupan suatu masyarakat.

Hal ini pun terjadi di Indonesia, di mana Islam yang ada di Indonesia merupakan hasil dari proses dakwah yang dilaksanakan secara kultural, sehingga Islam di Indonesia, mampu berkembang dan menyebar serta banyak dianut oleh mayoritas masyarakat Indonesia dalam waktu yang cukup singkat. Karena kehadiran Islam di Indonesia yang pada saat itu budaya lokal sudah dianut masyarakat Indonesia mampu masuk secara halus tanpa kekerasan, hal ini berkat dari ajaran Islam yang sangat menghargai akan pluralitas suatu masyarakat.

Banyak kajian sejarah dan kajian kebudayaan yang mengungkap betapa besar peran Islam dalam perkembangan kebudayaan bangsa Indonesia. Hal ini dapat di pahami, karena Islam merupakan agama bagi mayoritas penduduk Indonesia. Bahkan dalam perkembangan budaya daerah terlihat betapa nilai-nilai budaya Islam telah menyatu dengan nilai-nilai budaya di sebagian daerah di tanah air, baik dalam wujud seni budaya, tradisi, maupun peninggalan fisik. Sementara itu dalam pengembangan budaya nasional, peran Islam dalam terbentuknya wawasan persatuan dan kesatuan bangsa telah dibuktikan dalam sejarah. Islam dapat menjadi penghubung bagi berbagai kebudayaan daerah yang sebagian besar masyarakatnya adalah Muslim. ${ }^{48}$

Peran tersebut secara ekplisit dikemukakan oleh Presiden pada sambutan Seminar Nasional Budaya Bangsa 10 November 1995, bahwa "Agama bukan saja telah menghindarkan berkembangnya yang sempit, tetapi secara tidak langsung juga ikut meletakan dasaar-

\footnotetext{
${ }^{48}$ Wardiman Djojonegoro, dalam Ruh Islam Dalam Budaya Bangsa, Wacana Antar Agama dan Bangsa (Jakarta, Yayasan Festival Istiqlal, 1996), h.112.
} 
dasar kebudayaan nasional...", ajaran agama yang dianut oleh bangsa kita telah memberikan motivasi yang kuat bagi tumbuh dan berkembangnya pergerakan kebangsaan, lancarnya proklamasi kemerdekaan, gigihnya perjuangan bersenjata mengusir penjajah dan terarahnya pembangunan nasional ". Walaupun pengaruh nilai-nilai Islam telah nyata dalam perkembangan seni budaya nasional, namun pengaruh tersebut lebih ditekankan kepada upaya perkembangan budaya nasional dalam makna yang dinamis.

Bangsa Indonesia yang terdiri atas berbagai suku bangsa, agama dan kebudayaan lokal, perlu menumbuhkan dua macam sistem budaya itu yaitu: sistem budaya nasional (supra etnik), sistem budaya daerah (etnik). Sementara itu, bangsa Indonesia yang terdiri dengan banyak suku bangsa dengan sistem budaya etnik-lokanya masing-masing. Sistemsistem budaya yang otonom itu ditandai oleh pewarisan nilai-nilai melalui tradisi. Nilainilai tersebut telah berakar kuat dalam masyarakat yang bersangkutan. Seterusnya, dalam masyarakat etnik lokal itu sepanjang waktu terjadi vitalisasi dan aktualisasi nilai-nilai budayanya yang khas. Dalam rangka perkembangan budaya nasional, kebudayaan etnik lokal itu sering kali berfungsi sebagai sumber atau sebagai acuan dalam penciptaanpenciptaaan baru (dalam bahasa, seni, tata masyarakat, teknologi, dan sebagainya) yang kemudian ditampilkan dalam peri kehidupan lintas budaya. Sistem-sistem budaya etnik lokal inilah yang pada umumnya memberikan rasa berakar kepada rakyat Indonesia. Berdasarkan kondisi di atas, diperlukan strategi untuk mencapai dua tujuan dasar pembinaan kebudayaan, yaitu:

1) Semakin kuatnya nilai-nilai penghayata nilai-nilai budaya nasional agar mampu menyongsong masa depan bangasa yang ditandai oleh semakin canggihnya perkembangan ilmu pengetahuan dan teknologi dan semakin meningkatnya persaingan ekonomi antar bangsa dan semakin kompleksnya arus informasi dan proses penduniannya yang lain.

2) Semakin kokohnya kesadaran bangsa akan jati dirinya yang ditandai oleh pewarisan nilai-nilai luhur, kokohnya kehidupan beragama, kesadaran sejarah dan daya cipta yang dimiliki. ${ }^{49}$

Agama Islam pada prinsipnya sangat menghargai beraneka ragamnya budaya lokal yang ada, sehingga menjadikan agama Islam sebagai agama yang beragam dalam tataran ritualnya. Dalam kenyataan sosial, ajaran agama Islam mampu mewarnai keberadaan budaya suatu masyarakat, sehingga budaya lokal yang dianut oleh suatu masyarakat cenderung untuk beraktualisasi dengan ajaran agama Islam di dalam tata pelaksanaan ritualnya.

\section{Persentuhan Agama Islam dengan Kebudayaan Sunda}

Upaya untuk lebih memperjelas persentuhan Agama Islam dengan Kebudayaan

${ }^{49} \mathrm{Ibid}$, h. 109-110. 
Asli Masyarakat Indonesia, penulis mencoba untuk memunculkan persentuhan agama Islam dengan kebudayaan Sunda. Islam di Tatar Sunda muncul dalam wajah yang lebih egaliter, harmonis, jauh dari kekerasan struktural maupun kultural dan memiliki kepribadian yang jauh lebih dari sekedar Islam dalam arti sebatas fenomena saja. Oleh sebab itu, maka Islam di Tatar Sunda layak menjadi Islam sebuah mazhab. Bila kita melihat konteks mazhabmazhab hukum Islam, maka mazhab-mazhab tersebut pada awalnya dibentuk berdasarkan klaim daerah, seperti mazhab Irak, Madinah, Bashrah, dan Kufah. Kemudian kelompokkelompok ini mengalami perubahan bentuk dari organisasi berdasarkan daerah menjadi organisasi berdasarkan kesetiaan kepada tokoh tertentu. Perubahan ini dimulai pada periode asy-Syafici. ${ }^{50}$

Fenomena di atas kiranya dapat disaksikan di Tatar Sunda, di mana keberadaan Islam di Tatar Sunda dapat diibaratkan seperti gula dan manisnya (jiga gula jeung peupeutna) karena, dalam kenyataannya, perkembangan Islam di Tatar Sunda seiring sejalan dengan kondisi asli (local genium) masyarakat Sunda itu sendiri. Islam lebih mudah berinteraksi dengan sistem dan nilai yang berlaku pada saat itu. Di sinilah titik pertemuan antara Islam dengan kebudayaan Sunda dapat lebih dimaknai.

Mazhab dalam tulisan ini adalah mazhab dalam arti tradisi Islam, bukan dalam pengertian hukum (fiqh atau ushul fiqh). Dengan demikian Islam mazhab Sunda dapat dikatakan sebagai Islam yang mendasarkan cara pandangnya kepada ajaran-ajaran Islam yang masuk ke dalam tradisi masyarakat Sunda sehingga menghasilkan tradisi Islam yang bercorak lokal akibat dari perpaduan antara ajaran-ajaran Islam dengan kultur dan tradisi masyarakat Sunda. Islam mazhab Sunda yang menghasilkan tradisi Islam, mengutip pendapat Sayyed Hossein Nasr adalah perpaduan antara wahyu yang diterima Nabi dalam bentuk Kitab Suci dan bahwa Islam sebagai agama diserap sesuai dengan fitrahnya sendiri dan berhasil mencapai jati dirinya peralihan dan sintesis. Tradisi Islam mencakup semua aspek religi dan percabangannya berdasarkan apa yang dicontohkan oleh para wali.

Tradisi Islam ibarat sebuah pohon. Akarnya berada pada wahyu, dari akar ini tumbuhlah sekian banyak cabang dan ranting. Intinya adalah agama dan getahnya mengandung barakah, kebenaran suci, abadi dan tak tergantikan, kearifan abadi, dan penerapannya yang terus berkesinambungan sesuai dengan kondisi zaman. Tradisi Islam mencakup banyak hal, di antaranya meliputi pengetahuan, cara memandang dunia, nilai, dan jiwa kitab suci. ${ }^{51}$ Islam sebagai ajaran menjadi sumber nilai bagi terbentuknya cita budaya Islam dalam komunitas Sunda. Cita budaya itu tampak dalam bentuk gagasan yang kemudian

${ }^{50}$ George A Makdisi, Cita Humanisme Islam: Panorama Kebangkitan Intelektual dan Budaya Islam dan Pengaruhnya terhadap Renaisans Barat, Terj. A. Syamsu Rizal \& Nur Hidayah (Yogyakarta: PT. Serambi Ilmu Semesta, 2005), h.49.

${ }^{51}$ Muhaimin AG, Islam dalam Bingkai Budaya Lokal: Potret dari Cirebon, Cet. II (Jakarta: PT Logos Wacana Ilmu, 2002), h. 13. 
membentuk pranata-pranata sosial yang bercorak keislaman. Sisi terluar dari cita budaya tersebut membentuk benda-benda budaya yang dengan mudah dapat dikenali mengandung cita budaya Islam atau tidak. Sedangkan sisi terdalamnya, meskipun lebih abstrak dapat dilihat dalam bentuk sistem kehidupan sosial yang menjadikan Islam sebagai acuan utamanya.

Terdapat dua asumsi, minimalnya yang menyebabkan Islam dengan mudah menjadi bagian dari kehidupan orang Sunda. Pertama, agama Islam yang datang dan diterima oleh masyarakat Sunda merupakan sebentuk ajaran yang mudah dicerna dan dipahami sesederhana karakter budaya orang Sunda itu sendiri. Kedua, kebudayaan yang membungkus ajaran Islam tersebut merupakan kebudayaan yang membungkus ajaran Islam tersebut merupakan kebudayaan yang mudah bersinergis dengan budaya Sunda. Oleh karena itu, ketika proses Islamisasi di Tatar Sunda menyebar, maka Islam secara tidak langsung membentuk jati diri kesundaan orang sunda terintegralkan secara natural dalam prilaku keseharian sekaligus menjadi identitas permanen orang Sunda. ${ }^{52}$ Dari firman Allah SWT. dalam Q.S. Al-Baqarah/2: 134, 141, 148, QS. Yunus/10: 48, Q.S. Hud/11: 118 serta ayat-ayat yang setema dengan ayat di atas, maka pada dasarnya setiap umat memiliki pola dan ragam dalam menyikapi keislamannya. Demikian pula dengan umat Islam di Tatar Sunda. Hal ini dipertegas oleh al-Qur'an itu sendiri, yang menyatakan:

"Dan Kami telah turunkan kepadamu al-Qur' an dengan membawa kebenaran, membenarkan apa yang sebelumnya, yaitu kitab-kitab (yang diturunkan sebelumnya) dan batu ujian terhadap kitab-kitab yang lain itu; maka putuskanlah perkara mereka menurut apa yang Allah turunkan dan janganlah kamu mengikuti hawa nafsu mereka dengan meninggalkan kebenaran yang telah datang kepadamu. Untuk tiap-tiap umat diantara kamu, Kami berikan aturan dan jalan yang terang. Sekiranya Allah menghendaki, niscaya kamu dijadikan-Nya satu (saja), tetapi Allah hendak menguji kamu terhadap pemberian-Nya kepadamu, maka berlomba-lombalah berbuat kebajikan. Hanya kepada Allah-lah kembali kamu semuanya, lalu diberitahukan-Nya kepadamu apa yang telah kamu perselisihkan itu". ${ }^{53}$

Secara tersurat, ayat di atas memberikan petunjuk bahwa tiap-tiap umat pasti akan diberikan cara dan petunjuk dalam mengaktualisasikan cara keberagamaannya. Melihat dalam kondisi Tatar Sunda, maka Islam yang dipahami tentu saja sesuai dengan kondisi masyarakatnya, yaitu masyarakat Sunda. Maksudnya bahwa Islam sebagai suatu sistem nilai memberi umpan kepada budaya dengan memberi bentuk dan warna tertentu, sebaliknya sebagai sistem budaya, hampir tidak bisa dihindari telah memberikan umpan balik kepada Islam dengan memberikan peluang untuk tumbuh berkembangnya pandangan, pemahaman, pengalaman keagamaan dan corak tertentu dalam mengaktualisasikan keberagamaannya.

${ }^{52}$ Dadang Kahmad, "Agama Islam dan Budaya Sunda", dalam buku Ajip Rosidi, Edi S. Ekajati dan A. Chaedar Alwasilah (Penyunting). Konferensi Internasional Budaya Sunda Jilid I (Bandung, PT. Kiblat Buku Utama, 2006), h. 322.

${ }^{53}$ Q.S.al-Maidah/5 : 48. 
Kebudayaan Sunda adalah sumber kerangka acuan masyarakat Sunda, ketika mereka berhadapan dengan pelbagai perubahan. Suatu perubahan itu ditolak atau diterima oleh masyarakat tergantung sejauh mana perubahan itu bisa diterima oleh kebudayaannya. Oleh karena itu, suatu perubahan yang akan dilakukan terhadap masyarakat Sunda mesti mempertimbangkan aspek tradisi dan kebudayaan masyarakat Sunda itu sendiri. Ketika suatu yang berasal dari suatu unsur kebudayaan asing terlalu berbeda jauh dengan kebudayaan Sunda, perubahan itu akan sangat lama diterima menjadi bagian dari kebudayaan Sunda. ${ }^{54}$

K.H. Hasan Mustofa yang dikenal sebagai penghulu Bandung dan juga sastrawan Sunda, memberikan penafsiran pada ayat-ayat awal Surah al-Baqarah dengan pernyataan bahwa: "Urang Sunda mah geus Islam memeh Islam." "K5enyataan ini dapat dibuktikan bahwa hampir seluruh ranah kehidupan orang Sunda mengandung nilai-nilai yang Islami. Ajaran dan hukum dalam masyarakat Sunda pun disosialisasikan melalui seni dan budaya, seperti pada lakon pewayangan (wayang golek), lagu-lagu, pantun, dan banyolan-banyolan.

Ajaran Islam melalui media wayang golek meliputi Islam sebagai a way of life, termasuk ajaran dasar tentang ketatanegaraan dan pemerintahan. Ajaran Islam melalui pewayangan seringkali menekankan ketaatan kepada ajaran agama dan negara secara bersamaan dan berkesinambungan yang mencerminkan pemahaman atas perintah ketaatan kepada Allah, Rasul dan ulil amri sebagaimana diamanatkan dalam al-Qur'an. ${ }^{56}$ Demikian pula kredo yang dilambangkan dengan jimat layang kalimusada dalam cerita pewayangan Sunda (wayang golek) yakni dua kalimat syahadat menjadi pemicu gerak dan langkah manusia Sunda yang dapat menjadi penawar bagi penyelesaian berbagai masalah kehidupan dan juga penyakit.

Lagu-lagu Sunda pun sarat dengan ajaran dan hukum Islam, baik yang melembaga, seperti lagu-lagu Cigawiran, Ciawian, dan Cianjuran, ${ }^{57}$ maupun lagu-lagu yang biasa didendangkan oleh para santri kalong di mesjid, tajug, madrasah yang meliputi ajaran tauhid, hukum hingga ajaran tentang hidup berkeluarga, seperti pada lagu-lagu sawer panganten. Ajaran tauhid seringkali didendangkan melalui sifat dua puluh yang terumuskan oleh al-iji dan dikaji di pesantren dan mesjid-mesjid dalam Kitab Tijan dan Qathr al-Ghayats. Bahkan, tak jarang pula didendangkan oleh para inohong Sunda dalam upacara memperingati tahun baru Hijriyah.

${ }^{54}$ Dadang Kahmad, "Agama Islam dalam Perkembangan Budaya Sunda", dalam buku Cik Hasan Bisri, dkk (Penyunting), Pergumulan Islam dengan Kebudayaan Lokal di Tatar Sunda (Bandung: Kaki Langit, 2005), h. 69.

${ }^{55}$ Juhaya S. Praja,"Hukum Islam dalam Tradisi dan Budaya Masyarakat Sunda". Dalam buku Cik Hasan Bisri, h. 157-169.

${ }^{56}$ Q.S. an-Nisa/4 : 59

${ }^{57}$ Lihat kajian tentang Cigawiran dalam tulisan Asep Nurjamin,"Cigawiran: Tembang Sunda dari Pesantren", dalam buku Cik Hasan Bisri, h. 157-169. 
Ajaran Islam sebagai agama pun telah melembaga dalam upacara adat, khususnya perkawinan. Pesta perkawaninan ternyata mengadopsi istilah walimah dalam teks hadis yang menyerukan upacara atau pesta perkawinan awlim walau bisyatin. Sementara kedudukan wanita sebagai "ibu" rumah tangga dan pria sebagai "pencari" nafkah digambarkan dalam kalimat pamajikan yang menurut sastrawan Sunda berasal dari bahasa Arab, faamaji 'uka (tempat kembali setelah mencari nafkah).

Sedangkan ajaran hukum kewarisan Islam disosialisasikan dalam kalimat sageugeus saeundan atau sakelek satanggungan, yang memiliki konotasi bahwa laki-laki itu memiliki bagian 2 (dua), adapun perempuan adalah 1 (satu) atau bagian wanita sesuai kapasitas dan adikodratinya yang setengah kemampuan memikul barang yang dapat dilakukan seorang lelaki. ${ }^{58}$ Ajaran dan pemahaman atas hukum poligami pun dapat kita telusuri dalam lagu-lagu orang Sunda yang diplesetkan, antara lain:

$$
\begin{gathered}
\text { Halo-Halo Bandung } \\
\text { Ibu Kota Periangan } \\
\text { Boro-boro nyandung } \\
\text { Hiji ge teu kaparaban }
\end{gathered}
$$

Lagu di atas mengandung ajaran bahwa nyandung,yang dipahami orang sunda, hanya yang dibolehkan bagi yang mampu memberikan nafkah kepada istri-istrinya dan tentu saja dibarengi dengan keadilan. Orang Sunda pun dituntut untuk memiliki sifatsifat Rasul, yakni shidiq, fathanah, tabligh dan amanah yang tergambarkan dalam kalimat cageur, bageur, singer tur pinter. Dalam mencapai sifat-sifat tersebut, orang Sunda diwajibkan menuntut ilmu dan mencari rezeki dalam kalimat ilmu tuntut dunya siar. Sedangkan dalam melaksanakan tugas-tugasnya, baik sebagai individu dan keluarga, maupun sebagai anggota masyarakat, ia harus melaksanakan apa yang wajib dan yang sunah secara berkesinambungan sebagaimana terungkap dalam peribahasa fardu kalaku sunat kalampah. ${ }^{59}$

Sementara itu, rujukan ajaran Islam pun disosialisasikan dengan perkembangan zaman, antara lain dalam bentuk cetakan, baik tafsir bahasa Sunda, ${ }^{60}$ hadis, maupun hukum Islam atau fiqh. Hukum Islam ada yang dicetak dalam bahasa Sunda dengan menggunakan

${ }^{58}$ Juhaya S. Praja, h. 135.

${ }^{59}$ Ibid, h. 136.

${ }^{60}$ Tokoh tafsir dalam bahasa Sunda yang sanagat berpengaruh dan terkenal adalah Kyai Haji Ahmad Sanusi seorang ulama Tatar Sunda yang memiliki karya-karya dalam bidang keagamaan yang terbilang prestius. Beliau adalah seorang yang mumpuni dalam bidang tafsir. Gunseikasbu menyatakan bahwa karangan beliau mencapai 102 buah dalam bentuk bahasa Sunda dan 24 dalam bahasa Indonesia, menurut A. Mukhtar Mawardi berjumlah 75 buah, menurut S. Wanta berjumlah 480 macam buku sedangkan menurut Husen Hasan Basri, sampai saat tulisan ini dibuat berjumlah 45 judul. Paparan elaborativ tentang hal ini bisa dilihat dalam Husen Hasan Basri,"Islam di Sunda: Sebuah survei Penyelidikan terhadap Karya-Karya Kyai Haji ahmad Sanusi". Dalam buku Ajip Rosidi, Edi S. Ekajati dan A. Chaedar Alwasilah, Konferensi Internasional Budaya Sunda (Bandung: PT Kiblat Buku Utama, 2006), h. 361-387. 
huruf Arab dan dewasa ini dicetak dalam huruf lain, seperti Tafsir Al-Bayan dan Tafsir Rahmat. ${ }^{61}$ Pengaruh Arab Islam pun nampak sekali dalam bahasa Sunda, seperti jisim abdi untuk menyebut diri sendiri yang sepenuhnya diambil dari bahasa Arab, yaitu jisim (badan) dan 'abd (hamba), yakni hamba dalam pengertian Allah. ${ }^{62}$

Berdasarkan penjelasan di atas, menunjukan betapa Islamnya tata kehidupan orang Sunda, maka tidak berlebihan apabila Islam Sunda dijadikan sebuah mazhab. Terlebih jika kita melihat kenyataan bahwa sejak zaman kerajaan Sunda dan Galuh suasana keberagamaan masyarakat Sunda telah menciptakan kehidupan harmonis dalam semua bidang kehidupan. Terdapat beberapa hal menarik yang patut diapresiasi tentang keberagamaan masyarakat Sunda sebelum masuknya Islam ke tatar Sunda. Pertama, adanya kebebasan dalam beragama sehingga orang bebas untuk memilih agama dan sekte menurut keyakinannya masing-masing. Kedua, terjadinya sinkretisme dalam ajaran agama dan kepercayaan, misalkan animisme, Hinduisme, Budhisme, dan Islam, semua agama tersebut mengalami sinkretisme dalam perjalanan hidup manusia. Ketiga, kedua hal yang disebutkan di atas berlangsung secara damai dan alamiah sehingga tidak pernah terjadi konflik antara penganut agama yang satu dengan penganut agama yang lain. ${ }^{63}$

Lebih lanjut, menurut Edi S. Ekadjati, kajian atas sumber-sumber informasi mengenai keagamaan pada zaman Sunda masa lampau menunjukkan bahwa masyarakat Sunda telah memiliki gambaran tentang beberapa konsep yang esensial. Pertama, gambaran tentang ketuhanan menurut persepsi orang Sunda sendiri. Kedua, gambaran tentang kehidupan sesudah kematian, Ketiga, gambaran tentang cara-cara untuk mendapatkan keselamatan di dunia dan di akhirat dengan melakukan amal dan tapa sesuai dengan kedudukannya. ${ }^{64}$

Selain itu juga, menurut Residen Priangan Oosthout, orang Sunda lebih bersemangat dan teguh dalam beragama ketimbang orang Jawa. Misalnya, menurut Kern, pada tahun 1925 di wilayah Keresidenan Priangan, tidak ada kabupaten yang penduduknya demikian kuat dan tinggi perhatiannya dalam mempelajari pengetahuan agama, serta berkembang demikian baik seperti Cianjur. Bahkan, perkataan kafir, musyrik atau syirik pada waktu

${ }^{61}$ Untuk membuktikan betapa eratnya pergumulan budaya Sunda dengan ajaran Islam, maka pada tahun 1997 terbitlah al-Qur'an Mushaf Sundawi yang pembuatannya memakan waktu 1,5 tahun (dimulai pada tanggal 14 Agustus 1995 sampai dengan Januari 1997), dalam proses pembuatannya melibatkan beberapa unsur, yaitu pakar Ilmu al-Qur'an, kaligrafer, MUI, para seniman, budayawan, dan bahkan lembaga resmi seperti Lajnah Pentashih dari Departemen Agama RI. Lebih lanjut, lihat Agus Ahmad Safe'i, "Fenomena Kultural Islam-Sunda", dalam buku Cik Hasan Bisri, h. 141-145.

${ }^{62}$ Juhaya S. Praja, h.137.

${ }^{63}$ Edi S. Ekadjati, Kebudayaan Sunda: Zaman Pajajaran (Jakarta: PT Dunia Pustaka Jaya, 2005), h. 172.

${ }^{64} \mathrm{Ibid}$, h. 175. 
itu, sangat menyinggung harga diri orang yang mengaku Islam meskipun dalam tataran praksis banyak menjalankan ajaran-ajaran sinkretis. ${ }^{65}$

\section{Penutup}

Agama Islam sebagai agama universal dan agama bagi semesta alam, telah membuktikannya sebagai agama besar yang menghargai akan keberadaan budaya lokal suatu masyarakat. Bila agama Islam dan budaya lokal berakulturasi, maka pemahaman keagamaan yang terjadi pada suatu masyarakat akan beragam pula. Hal ini menunjukan bahwa agama Islam akan senantiasa berbaur dengan budaya lokal dan akan mewarnai budaya lokal yang dianut oleh masyarakat, sehingga agama Islam dalam tataran ritualnya beragam.

Agama Islam dan budaya lokal (dalam pemahaman kepercayaan asli animisme dan dinamisme) di Indonesia merupakan dua komponen yang saling mendukung terhadap perkembangannya, dimana agama Islam berkembang karena menghargai budaya lokal, begitu pula budaya lokal tetap eksis karena mengalami perbauran dengan ajaran agama Islam.

Akulturasi agama Islam dengan kepercayaan asli Indonesia telah membentuk ciri yang khas pada masyarakat Indonesia. Sejak pengalaman sejarah yang paling awal, masyarakat Indonesia senantiasa menempatkan nilai-nilai agama Islam pada posisi yang sangat sentral dalam seluruh aspek kehidupannya. Fenomena tersebut termuat dalam falsafah hidup masyarakat Indonesia yang terakumulasikan pada dasar ideologi masyarakat Indonesia yaitu Pancasila. Sesungguhnya, Pancasila merupakan pandangan hidup bangsa yang diwarnai oleh semangat ajaran agama Islam.

Dalam kontek persentuhan Agama Islam dengan Kebudayaan lokal, maka akulturasi agama Islam dengan budaya Sunda telah membentuk ciri yang khas pada masyarakat

Sunda di Jawa Barat. Sejak pengalaman sejarahnya yang paling awal, masyarakat Jawa Barat senantiasa menempatkan nilai-nilai agama Islam pada posisi yang sangat sentral dalam seluruh aspek kehidupannya. Fenomena yang termuat dalam falsafah hidup orang Sunda yang tercermin pada ungkapan Silih Asih, Silih Asah, Silih Asuh sesungguhnya merupakan salah satu prinsip hidup yang diwarnai oleh semangat ajaran agama Islam.

\section{Pustaka Acuan}

AG, Muhaimin, Islam dalam Bingkai Budaya Lokal: Potret dari Cirebon, Cet. II. Jakarta: PT Logos Wacana Ilmu, 2002.

${ }^{65}$ Muhammad Iskandar, Para Pengemban Amanah: Pergulatan Pemikiran Kiai dan Ulama di Jawa Barat 1900-1950 (Yogyakarta: Mata Bangsa, 2001), h. 55-57. 
Ahmad Safe'i, Agus, "Fenomena Kultural Islam-Sunda", dalam buku Cik Hasan Bisri, Pergumulan Islam dengan Kebudayaan Lokal di Tatar Sunda. Bandung: Kaki Langit, 2005.

Beatty, Andrew, dalam Varieties of Javanese Religion, Alih Bahasa Achmad Fedyani Saefudin. Jakarta: RajaGrafindo Persada, 2001.

Djojonegoro, Wardiman, "Ruh Islam Dalam Budaya Bangsa", Wacana Antar Agama dan Bangsa, Jakarta: Yayasan Festival Istiqlal, 1996.

Ekadjati,Edi S. Kebudayaan Sunda: Zaman Pajajaran. Jakarta: PT Dunia Pustaka Jaya, 2005.

Garna, Judistira K, Ilmu-Ilmu Sosial, Dasar-Konsep-Posis., Bandung: Pascasarjana Unpad,

Geertz, Clifford, The Religion of Java. Glencoe: The Free Press, 1960.

Glasse, Cyril Glasse, Ensiklopedi Islam. Jakarta: RajaGrafindo Persada, 1999.

Hasan Basri, Husen, "Islam di Sunda: "Sebuah survey Penyelidikan terhadap Karya-Karya Kyai Haji ahmad Sanusi". Dalam buku Ajip Rosidi, Edi S. Ekajati dan A. Chaedar Alwasilah (Penyunting), Konferensi Internasional Budaya Sunda, Bandung: PT Kiblat Buku Utama, 2006.

Iskandar, Muhammad, Para Pengemban Amanah: Pergulatan Pemikiran Kiai dan Ulama di Jawa Barat 1900-1950. Yogyakarta: Mata Bangsa, 2001.

Kahmad, Dadang, Sosiologi Agama. Bandung: Remaja Rosdakarya, 2000.

Kahmad, Dadang, "Agama Islam dalam Perkembangan Budaya Sunda", dalam Cik Hasan Bisri, Pergumulan Islam dan Kebudayaan di Tatar Sunda. Bandung: Kaki Langit, 2005.

Kahmad, Dadang, "Agama Islam dan Budaya Sunda", dalam buku Ajip Rosidi, Edi S. Ekajati dan A. Alwasilah, Chaedar (Penyunting). Konferensi Internasional Budaya Sunda Jilid I. Bandung, PT. Kiblat Buku Utama, 2006.

Koentjaraningrat, Pengantar Ilmu Antropologi, Cet. VIII. Jakarta: Rineka Cipta, 1990.

Kuntowijoyo, Paradigma Islam, Interpretasi untuk Aksi. Bandung: Mizan,1994.

Makdisi, George, Cita Humanisme Islam: Panorama Kebangkitan Intelektual dan Budaya Islam dan Pengaruhnya terhadap Renaisans Barat, (terj.) A. Syamsu Rizal \& Nur Hidayah. Yogyakarta: PT. Serambi Ilm Semesta, 2005.

Miharja, Deni, "Integrasi Agama Islam dengan Kebudayaan Sunda”, Disertasi, Pascasarjana UIN SGD Bandung, 2013.

Nurjamin, Asep "Cigawiran: Tembang Sunda dari Pesantren”, dalam buku Cik Hasan Bisri, dkk. (Penyunting), Pergumulan Islam dengan Kebudayaan Lokal di Tatar Sunda. Bandung: Kaki Langit, 2005.

Praja, Juhaya S. Praja,"Hukum Islam dalam Tradisi dan Budaya Masyarakat Sunda". Dalam buku Cik Pergumulan Islam dengan Kebudayaan Lokal di Tatar Sunda, Bandung: Kaki Langit, 2005. 
Shihab, M. Quraish, "Era Baru, Fatwa Baru” Kata Pengantar dalam MB. Hooker, Islam Mazhab Indonesia: Fatwa-Fatwa dan Perubahan Sosial. Jakarta: Teraju, 2002.

Simuh, Islam dan Pergumulan Budaya Jawa, Jakarta: Teraju, 2003.

Simuh, “Aspek Mistik Islam Kejawen Dalam 'Wirid Hidayat Jati”, Dalam Ahmad Rifa'i Hasan (Ed.), Warisan Intelektual Islam Indonesia. Bandung: Mizan, 1987.

Soekanto, Soerjono, Sosiologi Suatu Pengantar. Jakarta: Raja Grafindo Persada, 1990.

Subagya, Rachmat, Agama Asli Indonesia. Jakarta: Yayasan Cipta Loka Caraka, 1981.

Sudrajat, Ajat, Tafsir Inklusif; Makna Islam. Yogyakarta: AK GROUP, 2004.

Suntiah, Ratu dan Maslani, Sejarah Peradaban Isla. Bandung: CV. Insan Mandiri, 2010.

Stange, Paul, The Sumarah Movement In Javanese Myticis. Unpublished PhD. Thesis, Universitas Of Wisconsin-Madison, 1980.

Suryana, Toto, dkk., Pendidikan Agama Islam. Bandung: Tiga Mutiara, 2007.

Syam, Nur, Islam Pesisir. Yogyakarta: LKiS, 2004.

Tim Ichtiar Baru van Hoeve, Ensiklopedi Islam. Jakarta: Ichtiar Baru van Hoeve, 1994.

Van Bruinessen, Martin, Tarekat Naksabandiyyah di Indonesia. Bandung: Mizan, 1992.

Woodward, Mark R., Islam in Java. Universitas of Arizona Press, 1989. 